Article

\title{
Spatial Movement of Urban Beggars in Denpasar City
}

\author{
Putu Indra Christiawan*, I Gede Astra Wesnawa, Aprilia Riszi I.D.S \\ Department of Geography Education, Universitas Pendidikan Ganesha, Indonesia \\ * Correspondence: indra.christiawan@undiksha.ac.id ; Tel.: +62-818-053-29239
}

\begin{abstract}
Urban beggars are social problems that are related to the poverty of citizen. In Denpasar City Bali Province, particularly in West Denpasar District, the beggars have specificity in activities of begging. Studies in this article demonstrate their specificity begging activity which can be evaluated from the spatial movement of beggars based on the place, time and the distance. Through the method of grounded research with qualitative analysis showed that: (1) the beggars have permanent objects to visit, which consist of shops, settlement and places of worship of the Muslim community, (2) begging activities performed every Friday for 6 hours from 08.00 to at 14.00, and (3) beggars not only walking, but also using public transportation to visiting the object that is relatively far from beggars lane. The findings of this study reinforces that begging has become a profession that is conducted in a structured and well-organized.
\end{abstract}

Keywords: urban beggars; spatial movement; socio-religious

\section{Introduction}

Beggars are one of the products of poverty whose existence can not be separated from the development of an urban area. The existence of beggars in urban areas is indirectly a consequence of the function of the city as the center of development. The city as a center of development will attract population movement and functions from outter city to the inner city or known as the centripetal movement (Yunus, 2006). The variety of pull factors of the inner city includes complete supporting facilities, high accessibility to the compliance of various needs and especially a great opportunity in order to improve welfare. The increasing growth of urbanization and the increase and the excessive density of population have caused problems such as suburbanization, hidden unemployment, false jobs, and the development of social problems such as begging in city environments (Ahamdi, 2010).

In general, this beggar phenomenon is the result of various factors, and one of the factors the most common is the uncontrolled rural-urban migration (Ogunkan and Fawole, 2009). Beggars are partial migrants who are not able to compete for jobs and a decent living in the city. There are various types of beggars. Some are blind, lame or crippled and so take to begging. Some people who lost their homes, become beggars. Child and orphan beggars are also very common. Some people are physically sound but undertake begging as their profession to enable to earn living easily. Some give up their family life and start begging. Poverty, loss of job, major diseases like tuberculosis, leprosy etc and other socio-economic problems lead to begging phenomenon (Gurav, 2015).

Low skills and limited expertise are caused the half of the population of migrants, mostly from rural areas marginalized from the wheel of urban development. Limited capital to return to his hometown results marginalized migrants are organizing themselves by begging, namely making money by begging in public in various ways and reasons to expect mercy from others. The existence of beggars will obstruct urban development. These obstacles may be the disruption of public order and security stability of the city, triggering crime, disturb the beauty of the city, as well as the environmental impact with regard to the spatial arrangement of the city. Thus, beggars are social problems related to the interests of the people, especially city residents feel the area where life and daily activities handled by the beggars (Paksi et al., 2006).

Bali as one of the provinces in Indonesia that developed on the basis of the world standards of tourism. Strength-based international standard tourism has spurred various developments and construction area of Bali, especially in the areas of tourist destination. A tourist destination, in 
addition to attract tourists, also become a magnet for a variety of people to earn a fortune. Muta'ali (2013) states that the Bali Province is an area which is becoming one of the concentration of economic resources in Indonesia, causing the population is also concentrated in the region. Denpasar City as the heart of the provincial capital that has a strategic location in South Bali tourist destination become the destination of immigrants. The impact of the strategic location is a high concentration of population in the Denpasar City.

Denpasar City that directed as the city of culture cannot be achieved in complete if the beggar is still a part of the cityscape. By the very nature of urban development vision of culture is to prioritize the preservation of cultural heritage as a symbol of the region's identity. The cultural heritage is further developed to encourage the regional development with regard to the aspects of sustainable development, namely the social, economic, and environmental aspect.

The existence of beggars will not only be a social problem, but also will affect the economic instability and the beauty of spatial visual of Denpasar City. The threat to the status of cultural vision of the city will be higher with the increasing number of beggars who live in Denpasar City. Iqbali (2005) shows an increase in the number of beggars is very sharp in terms of data on the number of homeless and beggars were sent home each year by the Social Welfare Department of Bali Province, which numbered 300 beggars in 2002, and amounted to 1.595 beggars in 2005. In other words, the number of beggars in the city of Denpasar has decreased. But, to realize the vision of the city of culture, the presence of beggars in Denpasar City should be eliminated wherever possible.

The existence of beggars in Denpasar City has become increasingly complex. The complexity of this beggar seen from the beggars appearance who no longer appropriate to the criteria of beggars in general. Beggars with their appearance is not like a beggar as shown in Figure 1.

Figure 1. Beggars Appearance in Denpasar City

(Source: Aprilia, 2016)

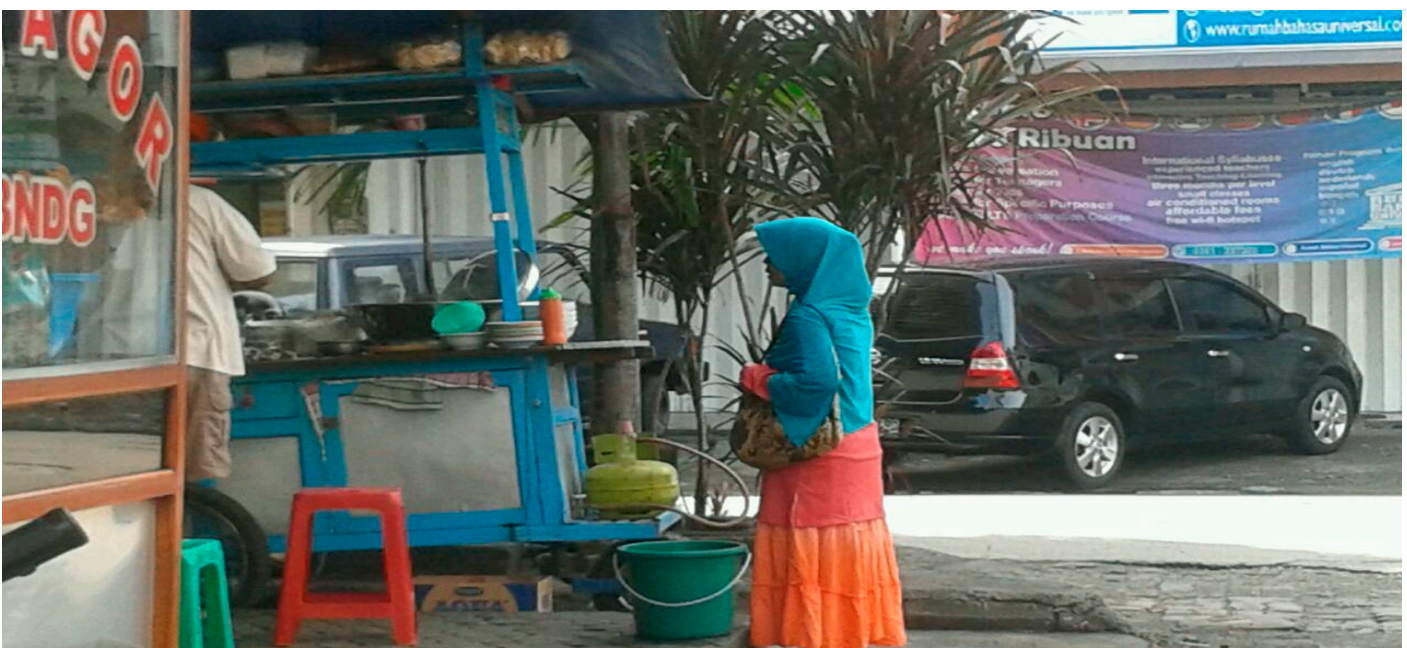

The major detention in reducing, and even eliminating the presence of beggars in Denpasar City is a lack of information and data about the pattern or location network where these beggars operate. Visionary idea to solve the problem is to prevent beggars operates from the first point they begin to begging, and oversee on each point traversed by these beggars. This study aims to assess the spatial movement of beggars in Denpasar City, particularly in West Denpasar District with emphasis on the dimensions of the place, time and distance from the activity of begging. Urgency of this study not only focuses on the reduction of beggars, but also to prevent beggar for beggars inherited for generations. Therefore, the handling of beggars, especially in urban areas is indispensable to prevent the nature of begging into an urban cultural heritage.

\section{Materials And Methods}

This study uses descriptive design. According to the design, this study aimed at the attempt indepth assessment of the spatial movement of beggars in West Denpasar District. Highly specialized 
nature of the object be a primary consideration for elaborate and explore in depth. Therefore, in order to obtain information related to spatial movement of beggars, the data collected by the grounded research technique with direct involvement in beggars community. Determination of the subject as key informants in this study defined snowball with the aim of obtaining answers directly from them. The collected data were analyzed qualitatively, to reveal the things associated with the process, not the product. Spatial approach, particularly spatial pattern analysis is a geographic approach used to understand the interrelationships between beggars and the location in space, so it will be acquired distinctiveness spatial movement of beggars.

\section{Result and Discussion}

West Denpasar District is one of four districts in Denpasar City which has the greatest number of beggars. Spatial movement associated with the beggars lane when carrying out its activities as shown in Table 1.

Table 1. Spatial Movement of Urban Beggars

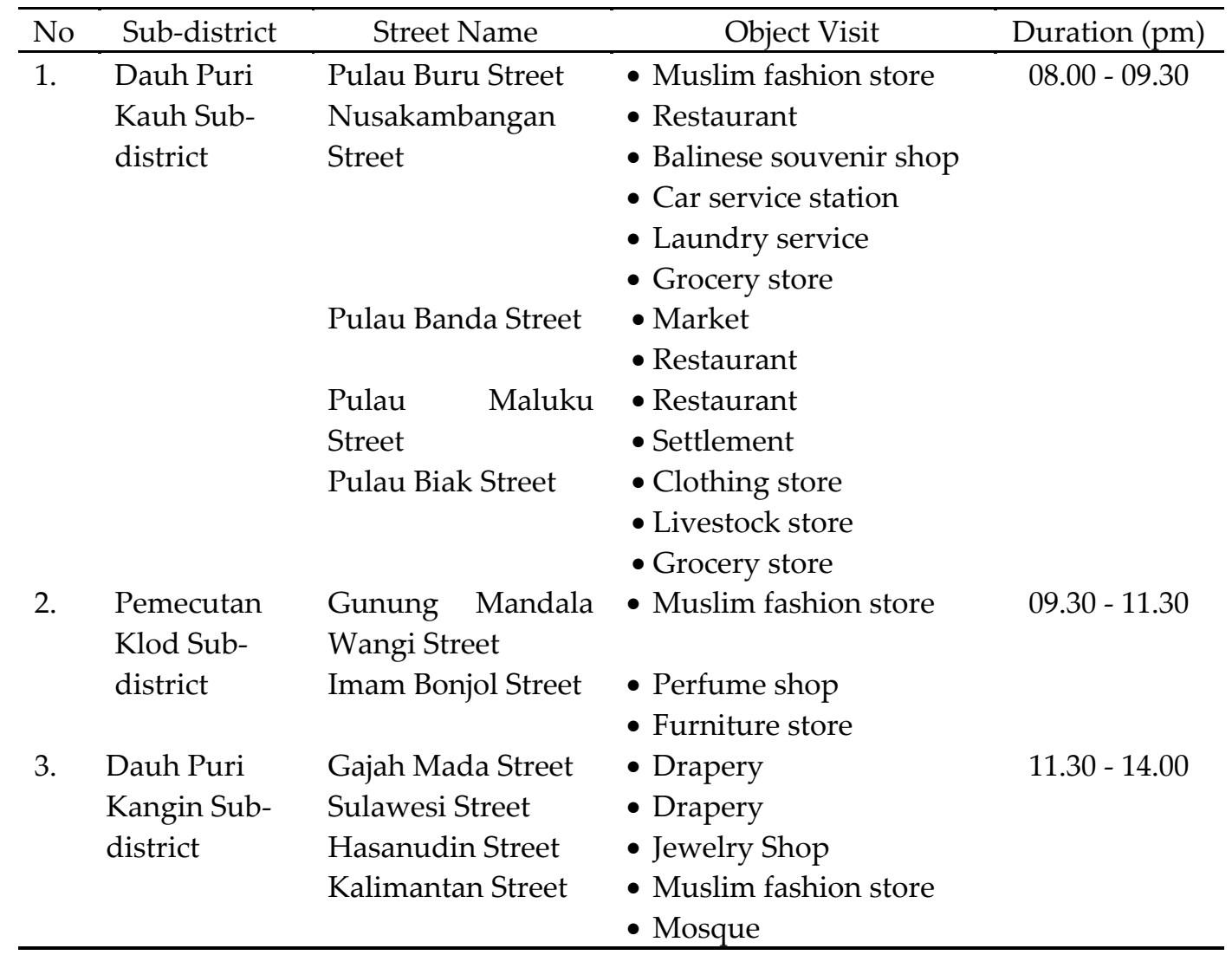

(Source: Primary Data, 2016)

Based on Table 1. there are three areas in West Denpasar District used as beggars lane. The three regions include the Dauh Puri Kauh Sub-district, Pemecutan Klod, and Dauh Puri Kangin Sub-district. First, beggars activities began in advance in Dauh Puri Kauh Sub-district. They use public transport to this location. This is because the distance to the first location relatively far away, or about $5 \mathrm{~km}$ from the area where they live. Beggars are in this district for 1.5 hours starting from 08.00 to $09.30 \mathrm{pm}$. In accordance with the begging lane, it appears that these beggars trip in Dauh Puri Kauh Sub-district consists of five street, which starts from Pulau Buru street and ends at Pulau Biak street. Site selection of Dauh Puri Kauh Sub-district as the first target area can not be separated from the characteristic of the place. Based on observations in the field, the place of the object visit spots in this sub-district is the center of the early economic activity, covering markets, shops, restaurants, and other retails in the sub-district.

All objects in the first place if viewed from nature are places compliance of primary needs. Characteristic of the center of economic activity that directly affects the time operational of work, 
therefore this places open earlier than the place for secondary or tertiary needs. This condition become consideration in the site selection of first place to begging, because that markets, shop, restaurants and other stores in Dauh Kauh Puri Sub-district had opened since $05.00 \mathrm{pm}$. These conditions cause this place became the starting point of the beggars movement in West Denpasar District. Besides the center of the primary economic activity, beggars also visited the settlements in Dauh Puri Kauh Sub-district. The settlements are being targeted of beggars only Muslim settlement, especially the houses owned by Arabs. Arabs settlements who become beggars lane is contained and clumped in Pulau Maluku street, or better known as the Kampung Arab.

Second, beggars continuing their activity to Klod Pemecutan Sub-district. Beggars were in this place for two hours starting at 09:30 to 11:30 pm. At this stage, they are only down two streets, namely Gunung Mandala Wangi and Imam Bonjol street. Although not as much as the streets is crossed as found in Dauh Puri Kauh Sub-district, but the lane of the street is relatively long and there are many objects to visit. The site elections of Pemecutan Klod Sub-district as the second place can be analyzed in terms of proximity from the place earlier, about $1 \mathrm{~km}$ and taken by walking. Administratively, Pemecutan Klod Sub-district directly adjacent to Dauh Puri Kauh Sub-district in the east. Because of its location adjacent to, beggars choose Pemecutan Klod Sub-district as the second place to begging. Among other sub-district, Pemecutan Klod Sub-district is a place with the largest Muslim population.

Based on data from the Social Service Denpasar in 2013 showed that the Dauh Puri Kauh Subdisrict ranked as the fourth largest Muslim population with a percentage of $11.9 \%$ of the total 11 sub-district in West Denpasar District. Meanwhile, Pemecutan Klod is a sub-district with the highest proportion of Muslim population, which amounted to 21.5\%, while the Dauh Puri Kangin Sub-district has the lowest proportion of Muslim population in West Denpasar District, which is only $1.6 \%$ of the total. Based on the type of object, it appears that the objects visit are places to compliance the secondary or tertiary needs. The place of secondary or tertiary economic activity be intended is Muslim fashion store, perfume shop and a furniture store. Characteristic of the center of secondary or tertiary economic activity influence on the time operating of the work. If in Dauh Puri Kauh Sub-district most of the object visit is already open at 5:00 pm, then at Pemecutan Klod Subdistrict these stores began to open at $09.00 \mathrm{pm}$. Most of the object visit is traversed by beggars is a store owned by Arabs. This becomes interesting finding that the object visit in Pemecutan Klod Sub-district visited by beggars only a place of business owned and run by Arabs community.

Third, beggars continuing their activity to Dauh Puri Kangin Sub-district as the third place. This sub-district is the last site of beggars to begging. The beggars are in this sub-district for 2.5 hours starting at 11:30 to 14:00 pm or the longest among the other place. There are four streets passed by beggars in Dauh Puri Kangin Sub-district, namely Gajah Mada street, Sulawesi street, Hasanuddin street and Kalimantan street.

At this stage, to get to the Dauh Puri Kangin Sub-district beggars using public transport (minibus). Mileage to the place is located approximately $3 \mathrm{~km}$ from the position of beggars in Pemecutan Klod Sub-district. Distance is the driving factor of beggars using public transportation to the object of this last visit. The object visit in Dauh Puri Kangin in nature have in common with the type of object visit in Pemecutan Klod Sub-distrcit. Most of the object in this place began to open at $09.00 \mathrm{pm}$. Although in general the object visit in the Dauh Puri Kangin Sub-district has in common with the nature of the object visit in other place, but there are differences in these place that distinguishes the two place earlier. The difference lies in the last object visit accosted by beggars, which is a mosque. The selection site, that isMosque in Puri Kangin Dauh Sub-district must not be separated from the time of begging activities, specifically every Friday. As has been seen previously, the beggars are in this sub-district starting at 11:30 to 14:00 pm. Meanwhile, on Friday, Muslims (male) has the obligation to worship on Sholat Jumat (Friday Prayer).

The moments of Sholat Jumat will be used by beggars in coin reap. Therefore, when the Sholat Jumat begin, the beggars had reached in Dauh Puri Kangin Sub-district, and they would look for a mosque not far from the end point of object visit in this place. Masjid Raya Ukhuwah be the right choice, because this mosque is located between the other several object visit of beggars in this sub- 
district. They will wait and put an end to its activity when the Muslim finished Sholat Jumat in the mosque located at Kalimantan street.

In almost every issue of religion in the world surrounding alms giving some money to the poor (and by implication begging) are entrenched though with different approaches. In this section the issue of alms giving and begging as obtained in the scriptures of Islam. In Islam, "zakat" (alms giving) is seen as one of the five pillars of the religion. It is believed that any money given to the poor is the guidance of Allah SWT. However, on the other hand, it can not be concluded that, if religion encourages to give alms, religion indirectly encourage beggars (Mnitp and Jelili, 2013). In other words, alms giving is something that must be done, especially on Friday, especially after Sholat Jumat. This has caused the beggar felt as to the socio-cultural entitled to receive alms giving from the citizens of other Muslims. These are the most strategic location and have a high degree of certainty for beggars to earn money by begging the Muslim after Sholat Jumat. Strategies undertaken by beggars in this place, especially at Masjid Raya Ukhuwah parallel with studies by Namwata et al. (2012), which indicates that one of the strategies beggar was sitting waiting in strategic places, and wait for the generosity and sympathy of potential lenders money.

Moreover, the reason Dauh Puri Kangin Sub-district election as a last place to visit may be viewed from the distance to the area of beggars residence. Dauh Puri Kangin Sub-district as a last place to visit have a shorter distance to the residence of a beggar, if compared to the previous two places that had been visited. Most beggars have a residence in the Ubung area, North Denpasar District, which can be reached by walking. This means that the choice of location beginning to end is completely structured very well, from choosing the object of the visit until characteristics of the time and distance it takes toward the residence of beggars.

Begging on urban streets is one of the activities that have been faced long ago and may be the work of a very vulnerable for individuals or communities are loaded with poverty (Namwata and Mgabo, 2014). The existence of an urban beggars are relfection of social phenomena that exist in every urban area. West Denpasar District as the center of economic activity that is run by Arabs and shelter largely Muslim population became the main target of the beggars. Another finding phenomenal is this beggar does not look like a beggar and had the permanent place, time and community as the object of their visit. Based on the exposure, some fundamental things that made the difference of each place as a lane begging outlined in Table 2 .

Table 2. The Difference of Begging Location

\begin{tabular}{|c|c|c|c|c|c|}
\hline \multirow[t]{2}{*}{$\overline{\mathrm{No}}$} & \multirow[t]{2}{*}{ Aspect } & \multicolumn{3}{|c|}{ Sub-district } & \multirow[t]{2}{*}{ Description } \\
\hline & & $\begin{array}{c}\text { Dauh Puri } \\
\text { Kauh }\end{array}$ & $\begin{array}{c}\text { Pemecutan } \\
\text { Klod }\end{array}$ & Dauh Puri Kangin & \\
\hline 1. & The place & $\begin{array}{l}\text { primary } \\
\text { economic } \\
\text { activity and } \\
\text { Kampung } \\
\text { Arab }\end{array}$ & $\begin{array}{l}\text { secondary or } \\
\text { tertiary } \\
\text { economic } \\
\text { activity }\end{array}$ & $\begin{array}{l}\text { secondary or } \\
\text { tertiary economic } \\
\text { activity and } \\
\text { Mosque }\end{array}$ & $\begin{array}{l}\text { the nature of object visit in } \\
\text { consideration to design } \\
\text { begging lane }\end{array}$ \\
\hline $\begin{array}{l}2 . \\
3 .\end{array}$ & $\begin{array}{l}\text { The time } \\
\text { The } \\
\text { distance }\end{array}$ & $\begin{array}{l}1,5 \text { hour } \\
\text { using public } \\
\text { transport } \\
\text { ( } 5 \mathrm{~km} \text { from } \\
\text { beggars } \\
\text { resident) }\end{array}$ & $\begin{array}{l}2 \text { hour } \\
\text { walking } \\
(1 \mathrm{~km} \text { from } \\
\text { the first } \\
\text { place/sub- } \\
\text { district) }\end{array}$ & $\begin{array}{l}2,5 \text { hour } \\
\text { using public } \\
\text { transport } \\
\text { ( } 3 \mathrm{~km} \text { from the } \\
\text { second place and } \\
1 \mathrm{~km} \text { from } \\
\text { beggars resident) }\end{array}$ & $\begin{array}{l}\text { duration of begging activity } \\
\text { factors in consideration to } \\
\text { choose transport modes }\end{array}$ \\
\hline
\end{tabular}

(Source: Primary Data, 2016)

This study is similar with studies by Paksi et al (2006) which showed that the beggar in Yogyakarta also carry out activities of begging on Friday. In addition, based on the type of object visit, there is one object visit is the same, that is Masjid. 
Based on the results of a study of the spatial movement, beggars of this type has its own beg lane that distinguishes it beggars in general in Denpasar City. In addition, other typical characteristics seen is the whole object visit of beggars belong to the Muslim community, be it stores, shops, settlement and places of worship. This means that the beggar will not begging other than in places belonging to the Muslims. This specificity is distinguishes between beggars in general with this type of beggars in Denpasar City.

\section{Conclusions}

The existence of beggars in West Denpasar District into a unique phenomenon that is considered important to be studied in depth. This is because a beggar in West Denpasar District has the novelty of the organization system of work and spatial movement. On the other hand, the specificity of the space and the target object is also a concern in answering the existence of beggars in West Denpasar District.

The spatial distribution of a this beggar in West Denpasar District consists of three location visits into the movement of beggars. The first location is Dauh Puri Kauh Sub-district. The second location is Pemecutan Klod, and the last is Dauh Puri Kangin Sub-district. The determination of these elections of begging location consideration of the characteristics of the place, time and distance, so that every location has the specificity of each other.

- The place, each visited object is based on socio-religious, ie the center of economic activity, settlement and the mosque became a place of business, residence and place of worship of Muslims or Arabs.

- The time, this beggar carrying out its activity for 6 hours, ie from at 8:00 to 14:00 pm.

- The distance, beggars started activities to begging on the location dominated the center of economic activity that serves the needs of primer by using public transport, followed by walk to the location that dominated the center of economic activity that serves the secondary or tertiary needs that open later than the previous location, and terminated on site the third using public transportation within the travel $3 \mathrm{~km}$ from the previous location, which is at the location where there are mosques, and at a location that has the shortest distance to their home. They can return to their home by walking.

The fact is some parts of the city such as shopping centers, residential areas, and places of worship become the main location of beggars, it is deemed to identify the pattern of beggars movement in the regions and for the installation of information and dissemination in these locations with the intent to make people aware not give money to beggars. Proper treatment by the police to the beggars seem necessary given the socio-religious in order to avoid aggressive behavior towards beggars.

\section{References}

Ahmadi, H., 2010. A Study of Beggars Characteristics and Attitude of People Towards the Phenomenon of Begging in the City of Shiraz. Journal of Applied Sociology, 39 (3): 135-148.

Gurav, R.B., 2015. Socio-Demographic Profile and Health Problems of Beggars in an Urban Area. International Journal of Scientific Research, 4(1): 420-422.

Iqbali, S., 2005. Case Study of Beggars in Kubu District Karangasem Regency (in bahasa). Jurnal Piramida, 4 (1). $1-13$.

Mnitp, RTP \& M.O. Jelili, 2013. Street-Begging in Cities: Cultural, Political and Socio-Economic Question. Global Journal Of Human Social Science Sociology \& Culture, 13 (5): 52-58.

Muta'ali, L., 2013. The Development of Rural Area (in bahasa). Yogyakarta: Badan Penerbit Fakultas Geografi (BPFG) UGM.

Namwata, B.M.L \& M.R Mgabo, 2014. Consequences of Begging and Future Aspiration of Beggars to Stop Begging Life in Central Tanzania. International Research Journal of Human Resources and Social Science, 1(4): 176-187. 
Namwata, B.M.L., M.R. Mgabo and P. Dimoso, 2012. Categories of Street Beggars and Factors Influencing Street Begging in Central Tanzania. African Study Monographs, 33 (2): 133-143.

Ogunkan, D.V. \& O.A. Fawole, 2009. Incidence and socio-economic dimensions of begging in Nigerian cities: The case of Ogbomoso. International NGO Journal, 4(12): 498-503.

Paksi, A. K., B.N. Nugroho and N.N. Susanto, 2006. Non-Economic Beggars Motivation of Yogyakarta City (in bahasa). Jurnal PKMP, 18 (3): 1-10.

Yunus, H. S., (2006), Megapolis: Concepts, Problems and Prospects (in bahasa), Pustaka Pelajar, Yogyakarta.. 